\title{
Correction to: Financial crisis and income- related inequalities in the universal provision of a public service: the case of healthcare in Spain
}

\author{
Ignacio Abásolo ${ }^{1,2}$, Marc Saez $^{3,4,5^{*}}$ and Guillem López-Casasnovas ${ }^{5,6,7}$
}

\section{Correction to: Int J Equity Health (2017) 16:134 https://doi.org/DOI 10.1186/s12939-017-0630-y}

Following publication of the original article [1], the authors indicated 5 references should have been reported in Spanish. The correct references can be found below:

4. Calonge S, Manresa A. Consecuencias distributivas y de equidad de las políticas de gasto y financiación de la sanidad. Moneda y Crédito. 1997; 204: 13-66. Google Scholar

5. Ortiz F, Abásolo I, Jiménez V. Sanidad Pública y Distribución de la Renta en España. En Políticas de Bienestar y Desempleo (coord. José M. Maravall Herrero). Madrid: Fundación Argentaria; 1999. Google Scholar

10. González-Álvarez ML, Clavero-Barranquero A. Análisis de las desigualdades socioeconómicas en la utilización de asistencia sanitaria mediante modelos dinámicos. Hacienda Pública Española. 2008; 186(3): 9-42. Google Scholar

11. Abásolo I, Pinilla J, Negrín M. Equidad en la utilización de servicios sanitarios públicos por Comunidades Autónomas en España: un análisis multinivel. Hacienda Pública Española.

2008;187(4):87-106. Google Scholar

12. Abásolo I, Negrín M, Pinilla J. Utilización y tiempos de espera: dos vertientes inseparables del análisis de la equidad en el acceso al sistema sanitario público. Hacienda Pública Española. 2014; 208: 11-38.

Google Scholar.

\begin{abstract}
Author details
'Department of Applied Economics and Quantitative Methods, University of La Laguna, La Laguna, Spain. 'University Institute of Regional Development, University of La Laguna, La Laguna, Spain. ${ }^{3}$ Research Group on Statistics, Econometrics and Health (GRECS) University of Girona, Carrer de la Universitat de Girona 10 Campus de Montilivi, 17003 Girona, Spain. ${ }^{4}$ CIBER of Epidemiology and Public Health (CIBERESP), Madrid, Spain. ${ }^{5}$ Center for Research in Health and Economics (CRES), University Pompeu Fabra, Barcelona, Spain. ${ }^{6}$ Department of Economics and Business, University Pompeu Fabra, Barcelona, Spain. ${ }^{7}$ Barcelona Graduate School (BSGE), University Pompeu Fabra, Barcelona, Spain.
\end{abstract}

Received: 26 April 2019 Accepted: 26 April 2019

Published online: 09 May 2019

\section{Reference}

1. Abásolo, et al. Financial crisis and income-related inequalities in the universal provision of a public service: the case of healthcare in Spain. Int J Equity Health. 2017;16:134. https://doi.org/10.1186/s12939-017-0630-y.

* Correspondence: marc.saez@udg.edu

${ }^{3}$ Research Group on Statistics, Econometrics and Health (GRECS) University of Girona, Carrer de la Universitat de Girona 10 Campus de Montilivi, 17003 Girona, Spain ${ }^{4}$ CIBER of Epidemiology and Public Health (CIBERESP), Madrid, Spain

Full list of author information is available at the end of the article

C The Author(s). 2019 Open Access This article is distributed under the terms of the Creative Commons Attribution 4.0 International License (http://creativecommons.org/licenses/by/4.0/), which permits unrestricted use, distribution, and reproduction in any medium, provided you give appropriate credit to the original author(s) and the source, provide a link to the Creative Commons license, and indicate if changes were made. The Creative Commons Public Domain Dedication waiver (http://creativecommons.org/publicdomain/zero/1.0/) applies to the data made available in this article, unless otherwise stated. 